\title{
Terrein induces apoptosis in HeLa human cervical carcinoma cells through p53 and ERK regulation
}

\author{
YUWARAT PORAMEESANAPORN ${ }^{1}$, WANLAYA UTHAISANG-TANECHPONGTAMB ${ }^{2}$, \\ FAONGCHAT JARINTANAN $^{3}$, SUCHADA JONGRUNGRUANGCHOK ${ }^{4}$ \\ and BENJAMAS THANOMSUB WONGSATAYANON ${ }^{1}$
}

\begin{abstract}
Departments of ${ }^{1}$ Microbiology and ${ }^{2}$ Biochemistry, Faculty of Medicine, Srinakharinwirot University, Bangkok 10110; ${ }^{3}$ Faculty of Medical Technology; ${ }^{4}$ Department of Pharmaceutical Chemistry, Faculty of Pharmacy, Rangsit University, Pathum Thani 12000, Thailand
\end{abstract}

Received October 25, 2012; Accepted January 9, 2013

DOI: 10.3892/or.2013.2288

\begin{abstract}
Terrein, a fungal metabolite derived from Aspergillus terreus, has been shown to have a variety of biological activities in human cells including inhibition of melanogenesis, as well as anti-inflammatory, antioxidant and anticancer properties. In the present study, terrein was shown to have marked anticancer activity on HeLa human cervical carcinoma cells. Terrein exhibited inhibition of proliferation within the same ranges for other cancer cell types with an $\mathrm{IC}_{50}$ at $0.29 \mathrm{mM}$. The growth inhibition that induced cell death was via apoptosis mechanisms. Chromatin condensation was observed using the Hoechst 33342 stain, a DNA-specific dye. The increase of DNA fragmentation or the sub-G0 peak was also detected by flow cytometry. The signaling used by terrein to induce apoptosis was via the death-receptor and mitochondrial pathways; the cleavage of specific fluorogenic substrates by caspase- $3,-8$ and -9 activities are clearly demonstrated. The mitochondria were damaged as demonstrated by the decrease of the red/green ratio of the JC-1 staining and the increase of the $\mathrm{Bax} / \mathrm{Bcl}-2$ expression ratio. Further analysis of the upstream signaling by the quantitative real-time polymerase chain reaction showed that $p 53, p 21$ and $E R K$ were upregulated which indicates the importance of their roles on terrein signaling. This study is the first to show that terrein has an effect on the anticancer properties in cervical cancer cells by inducing apoptosis through p53 and ERK regulation. Our data may help expand the function of the terrein compound and may also aid in the discovery of new anticancer agents.
\end{abstract}

Correspondence to: Dr Wanlaya Uthaisang-Tanechpongtamb, Department of Biochemistry, Faculty of Medicine, Srinakharinwirot University, Sukhumwit 23, Bangkok 10110, Thailand

E-mail: wanlaya@swu.ac.th

Key words: terrein, apoptosis, Bax/Bcl-2 ratio, caspase-8, caspase-9, ERK2, p53

\section{Introduction}

Human cervical carcinoma is the second most common cancer among women worldwide, with about 500,000 new cases and 250,000 related deaths occurring every year, primarily in developing countries (1). Cervical cancer can be cured by radical surgery or radiotherapy for the patients diagnosed with cervical cancer in the early stages, while chemotherapy or neoadjuvant chemotherapy is the primary option for patients with advanced cervical cancer (2). However, the available chemotherapeutic agents are not completely effective in patients with advanced cervical cancer due to the lower chemosensitivity of the cervical cancer cells. Therefore, effective chemotherapeutic agents are required to improve the 5-year survival rate of these patients (3). Cancer is a disease of uncontrolled cell growth or proliferation and a lack of apoptosis; therefore, any agent that can block the cell proliferation or induce apoptosis in the cancer cells could prove to be a potent anticancer agent. To date, several anticancer drugs (such as, paclitaxel, doxorubicin, etoposide and cisplatin) already in use in the clinical setting have been proven to be apoptosis-inducing agents (4-7). Thus, apoptosis induction is a promising direction in the development of new anticancer agents.

Several sources from plants, marine organisms and microorganisms are used to produce anticancer agents. In microorganisms, it has been shown that both bacteria and fungi are valuable sources of bioactive compounds. However, most anticancer drugs developed from microorganisms currently used in the clinical setting are from bacteria (8). The anticancer properties of metabolites from fungi have yet to be fully elucidated. Terrein $\left(\mathrm{C}_{8} \mathrm{H}_{10} \mathrm{O}_{3}\right)$ is a bioactive, fungal, secondary metabolite which was first isolated from Aspergillus terreus in 1935 (9). The chemical structure of terrein contains free hydroxyl groups at positions 4 and 5 of the cyclopentenone ring (Fig. 1) (10,11). Terrein has been reported to have several biological activities. It has been shown that terrein functions as a melanogenesis inhibitor by reducing the tyrosinase production in the spontaneously immortalized mouse melanocyte cell line of Mel-Ab $(11,12)$. In lipopolysaccharide (LPS)-induced inflammation of human 
dental pulp cells, terrein has been shown to function as an anti-inflammatory agent (13). In MC3T3-E1 fibroblast cells grown on a titanium surface, biocompatible material, terrein was found to reduce the oxidative stress demonstrating antioxidant activity (14). Aside from the activities mentioned, terrein has also been shown to suppress the proliferation of human skin keratinocyte cells (15). Markedly, terrein has been shown to inhibit the growth of several types of cancer cells. In prostate cancer cells, terrein has been reported to work as an angiogenesis inhibitor (16). In lung cancer, terrein has been shown to function as a proteasome inhibitor that promotes cell death by apoptosis (10). Additionally, terrein has suppressive growth effects in ABCG2-expressing breast cancer cells by inducing the apoptosis mechanism (17). Thus, terrein is a promising compound, particularly for its anticancer properties; it may provide a new option in cancer therapeutics. In this study, we further examined the anticancer properties of terrein in cervical cancer cells (HeLa), as well as the signaling induced through ERK, p53 and caspase-3, -8 and -9, which have yet to be reported for terrein function.

\section{Materials and methods}

Chemicals and reagents. Dulbecco's modified Eagle's medium (DMEM), Medium 199, fetal bovine serum (FBS), $0.25 \%$ Trypsin-EDTA, penicillin-streptomycin, TRIzol Reagent, Taq DNA Polymerase, SuperScript ${ }^{\circledR}$ VILO $^{\text {TM }}$ cDNA Synthesis kit and Hoechst 33342 were purchased from Gibco (Gaithersburg, MD, USA). Dimethyl sulfoxide (DMSO), RNase and propidium iodide (PI) were obtained from Sigma-Aldrich (St. Louis, MO, USA). Sodium citrate, dithiothreitol (DTT) and ethidium bromide were purchased from Sigma Chemical Co., (St. Louis, MO, USA). Material 3-(4,5-dimethylthiazol2-yl)-2,5-diphenyltetrazolium bromide (MTT) was obtained from USB Corp., (Cleveland, OH, USA) and agarose from Vivantis (Oceanside CA, USA). The JC-1 mitochondrial membrane potential assay kit was purchased from Biotium, Inc. (Hayward, CA, USA). The caspase colorimetric assay kit was from Calbiochem Merck KGaA (Darmstadt, Germany). Power SyBR ${ }^{\circledR}$ Green Master Mix was purchased from Applied Biosystems (Foster City, CA, USA).

Preparation of terrein. Terrein was extracted from the culture broth of fungi Aspergillus terreus CRI301. The crude extract was carried out using ethyl acetate as a solvent. The EtOAc extract was concentrated in vacuo, and then the crude extract from the broth was fractionated and purified by use of the Sephadex LH-20 (2 cm inner diameter and $125 \mathrm{~cm}$ long), using $\mathrm{MeOH}$ as an eluent. Spectroscopic analysis was used for the compound characteristics.

Cell culture and maintenance. The human cervical carcinoma cell line (HeLa) was kindly provided by Dr Mathurose Ponglikitmongkol, Department of Biochemistry, Faculty of Science, Mahidol University, Thailand. The immortalized porcine epithelial glandular (PEG) cells were kindly provided by Dr Chatsri Deachapunya, Srinakharinwirot University. The HeLa cells were maintained in DMEM supplemented with $10 \%$ FBS and with $1 \%$ penicillin-streptomycin. The PEG cells were cultured in DMEM containing 5\% FBS, $1 \%$ L-glutamine,

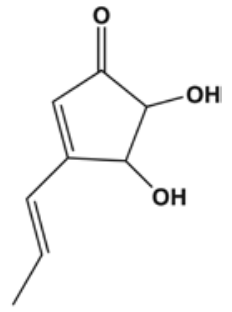

Figure 1. The structure of terrein.

$1 \%$ non-essential amino acid, $0.1 \%$ insulin and $1 \%$ penicillinstreptomycin. Both specimens were cultured at $37^{\circ} \mathrm{C}$ in a humidified atmosphere of $95 \%$ air and $5 \% \mathrm{CO}_{2}$.

Cytotoxicity assay. The cytotoxicity assay was performed by the MTT method (18). The HeLa and PEG cells at $1 \times 10^{4}$ cells/100 $\mu \mathrm{l} /$ well were seeded onto a 96 -well plate and incubated overnight. The cells were then treated with terrein at 5, 0.5, 0.05, 0.005, 0.0005 and $0.00005 \mathrm{mM}$ for $24 \mathrm{~h}$. An untreated group was combined with $1 \%$ DMSO and used as a negative control. Following $24 \mathrm{~h}$ of cell treatment, the MTT dye [Thiazolyl Blue Tetrazolium Bromide: (3-(4, 5-dimethylthiazol-2-yl)-2,5-diphenyltetrazolium bromide] was added at $0.5 \mathrm{mg} / \mathrm{ml}$ into each well and incubated for $3 \mathrm{~h}$. The formazan crystal products formed were dissolved by the addition of $100 \mu \mathrm{l}$ of DMSO. After $15 \mathrm{~min}$, the amount of purple formazan was determined by measuring the optical density (OD) using the ELISA microplate reader at $595 \mathrm{~nm}$. The experiment was performed in triplicate and the percentage of cell viability was calculated as: $\%$ Viability $=[\mathrm{OD}$ of treated cells/OD of control cells] x 100 .

Nuclear morphological observation. The effect of terrein on the nuclear morphological changes was investigated by Hoechst 33342 staining (19). Briefly, the HeLa cells at $4 \times 10^{5}$ cells/well were seeded onto a 12 -well plate and treated with terrein at $0,0.3,0.6$ and $1.5 \mathrm{mM}$ for $24 \mathrm{~h}$. At the end of the treatment, both the adherent and non-adherent cells were collected. Then, the cells were fixed with $3.7 \%$ (vol/vol) paraformaldehyde for $10 \mathrm{~min}$ at room temperature, permeated with $0.1 \%$ Triton $\mathrm{X}-100$ for another $10 \mathrm{~min}$ at room temperature and stained with Hoechst 33342 (1 mg/ml of phosphate-buffered saline; PBS) at $37^{\circ} \mathrm{C}$ for $15 \mathrm{~min}$. The nuclear morphology was observed with a fluorescent microscope (Olympus, Tokyo, Japan).

Analysis of apoptotic sub-G0 population. The sub-G0 population was analyzed using flow cytometry as previously described (20). The HeLa cells at $1 \times 10^{6}$ cells/well were plated on a 6-well plate and treated with terrein at 0, 0.3, 0.6 and $1.5 \mathrm{mM}$. After $24 \mathrm{~h}$, the treated cells were trypsinized and washed twice with ice-cold PBS. The cell pellet was resuspended in $1 \mathrm{ml}$ PBS and gently fixed (drop by drop) with $4 \mathrm{ml}$ of absolute ethanol at $-20^{\circ} \mathrm{C}$ for 5-15 min. Following centrifugation, the ethanol was discarded and $5 \mathrm{ml}$ of PBS was added to the cell pellet which was then allowed to rehydrate for $15 \mathrm{~min}$. Subsequently, each sample was incubated with $500 \mu \mathrm{l}$ of $100 \mu \mathrm{g} / \mathrm{ml} \mathrm{RNase}$ for $20 \mathrm{~min}$ at $37^{\circ} \mathrm{C}$. After washing with PBS, the cell pellet was gently resuspended in $500 \mu \mathrm{l}$ of PI solution $(50 \mu \mathrm{g} / \mathrm{ml}$ PI in $0.1 \%$ sodium citrate plus $0.1 \%$ Triton 
Table I. Oligonucleotides used in real-time PCR.

\begin{tabular}{lll}
\hline Gene & \multicolumn{1}{c}{ Forward primer } & \multicolumn{1}{c}{ Reverse primer } \\
\hline$p 53$ & 5'-ACTAAGCGAGCACTGCCCAA-3' & 5'-ATGGCGGGAGGTAGACTGAC-3' \\
$p 21$ & 5'-TATGGGGCTGGGAGTAGTTG-3' & 5'-AGCCGAGAGAAAACAGTCCA-3' \\
Bax & 5'-GCGTCCACCAAGAAGCTGAG-3' & 5'-ACCACCCTGGTCTTGGATCC-3' \\
Bcl-2 & 5'-TGTGGCCTTCTTTGAGTTCG-3' & 5'-TCACTTGTGGCCCAGATAGG-3' \\
ERK2 & 5'-GCCTGGCCCGTGTTGCAGAT-3' & 5'-CGCCCCTCCAAACGGCTCAA-3' \\
GAPH & 5'-GAAGGTGAAGGTCGGAGTCA-3' & 5'-GACAAGCTTCCCGTTCTCAG-3' \\
\hline
\end{tabular}

$\mathrm{X}-100)$ at $4^{\circ} \mathrm{C}$ in a darkened environment overnight. Each sample was measured using flow cytometry (BD FACSCanto, Becton-Dickinson, Lincoln Park, NJ, USA) using the Consort 30 program (Becton-Dickinson).

Caspase activity assay. Caspase-3, -8 and -9 activities were measured using fluorescent assay kit detection (Calbiochem Merck $\mathrm{KGaA}$ ), according to the manufacturer's instructions. Briefly, HeLa cells at $1 \times 10^{6}$ cells/well were placed on a 6-well plate, treated with terrein at $0,0.3,0.6$ and $1.5 \mathrm{mM}$ for $12 \mathrm{~h}$. After the treatment, supernatants from cell lysates were incubated with fluorogenic substrates using DEVD-AFC (caspase-3-like), IETD-AFC (caspase-8-like) and LEHD-AFC (caspase-9-like), at $37^{\circ} \mathrm{C}$ for $2 \mathrm{~h}$ prior to monitoring with a fluorescent microplate reader with excitation set at $400 \mathrm{~nm}$, and emissions at $505 \mathrm{~nm}$.

Analysis of mitochondrial transmembrane potential. The changes in mitochondrial membrane potential $(\Delta \Psi \mathrm{m})$ were detected using a 5,5',6,6'-tetrachloro-1,1',3,3'-tetraethyl-benzimidazolyl-carbocyanine iodide (JC-1) dye (Biotium Inc.). In healthy cells, the JC-1 accumulates in the mitochondria as JC-1 aggregates (fluorescence is red) and also in the cytoplasm as JC-1 monomers (fluorescence is green). In early apoptosis, the $\Delta \Psi$ m collapses, making JC-1 aggregates unable to accumulate within the mitochondria and dissipate into the JC-1 monomers leading to a loss of the red fluorescence. Therefore, collapse of the $\Delta \Psi_{\mathrm{m}}$ is exhibited by a decrease in the ratio of red to green fluorescence (21). In accordance with the terrein treatment, HeLa cells at $1 \times 10^{4}$ cells/well were placed on a 96 -well plate, treated with terrein at 0, 0.3,0.6 and $1.5 \mathrm{mM}$ for $6 \mathrm{~h}$. Following treatment, the cells were harvested and incubated with a JC-1 reagent solution at $37^{\circ} \mathrm{C}$ for $20 \mathrm{~min}$, then washed twice with PBS and suspended once more in the PBS. The samples were analyzed by a fluorescence microplate reader and measured with both the red fluorescence (excitation $550 \mathrm{~nm}$, emission $600 \mathrm{~nm}$ ) and the green fluorescence (excitation $485 \mathrm{~nm}$, emission $535 \mathrm{~nm}$ ). The ratio of red fluorescence intensity vs. green fluorescence intensity was calculated and presented as the means \pm SD. This experiment was performed in triplicate.

Real-time polymerase chain reaction (real-time PCR). To analyze the effect of terrein on the expression of apoptosisrelated genes ( $p 53, \mathrm{Bax}, \mathrm{Bcl}-2, \mathrm{p} 21$ and ERK2), real-time PCR was used. HeLa cells at $1 \times 10^{6}$ cells/well were plated on a 6-well plate, treated with terrein at $0,0.3,0.6$ and $1.5 \mathrm{mM}$ for $24 \mathrm{~h}$. Following treatment, the cells were harvested and washed with $500 \mu \mathrm{l}$ of PBS. The total RNA was extracted using a TRIzol Reagent (Invitrogen, Carlsbad, CA, USA) and quantified by use of OD measurement at 260 and $280 \mathrm{~nm}$ using a spectrophotometer (Thermo Fisher Scientific, Madison, WI, USA) (all RNA samples had an A260/A280 ratio >1.8).

The isolated total RNA $(2.5 \mu \mathrm{g})$ was reverse-transcribed to cDNA with the SuperScript VILO cDNA Synthesis kit (Invitrogen). The reaction mixture was composed of $4 \mu \mathrm{l}$ of $5 \mathrm{X}$ VILO reaction mix, $2 \mu 1$ of 10X SuperScript enzyme mixture, and DEPC-treated water in a total volume of $25 \mu 1$. The reaction mixture was incubated at $25^{\circ} \mathrm{C}$ for $10 \mathrm{~min}$, at $42^{\circ} \mathrm{C}$ for $60 \mathrm{~min}$ and the reaction was terminated by heating at $85^{\circ} \mathrm{C}$ for $5 \mathrm{~min}$. The resultant cDNA was stored at $-20^{\circ} \mathrm{C}$ until further use. The PCR primers were obtained from BioDesign Co., Ltd., Pathumthani, Thailand. PCR primers were designed by Primer 3.0 and BLAST search to check the specificity. The primer sequences used are listed in Table I.

Real-time quantitative-PCR was performed on an ABI StepOnePlus (Applied Biosystems), using 96-well microtiter plates. The reaction was carried out in a total volume of $20 \mu \mathrm{l}$, containing $2.5 \mu \mathrm{l}$ of the cDNA sample (equivalent to $75 \mathrm{ng}$ ), $1 \mu \mathrm{l}$ of $0.5 \mu \mathrm{M}$ each of the primer and $10 \mu \mathrm{l}$ of SYBR-Green Reaction Mix (Applied Biosystems). PCR amplification was performed in duplicated wells. The cycling conditions were: 10 min polymerase activation at $95^{\circ} \mathrm{C}$ and 40 cycles at $95^{\circ} \mathrm{C}$ for $15 \mathrm{sec}$ and $60^{\circ} \mathrm{C}$ for $60 \mathrm{sec}$. In addition, the real-time reaction of the products was examined by analyzing the melting point after each reaction. A sample without cDNA was used as a negative control and glyceraldehyde-3-phosphate dehydrogenase (GAPDH) was used as an internal control. The baseline and the threshold were set automatically by the software. The crossing point of the amplification curve with the threshold represents the cycle threshold $(\mathrm{Ct})$. The fluorescence threshold $\mathrm{Ct}$ values were calculated, and the $\Delta \mathrm{Ct}$ values were determined using the formula $\Delta \mathrm{Ct}=\mathrm{Ct}_{\text {target gene }}-\mathrm{Ct}_{\mathrm{GAPDH}}$. The $\Delta \Delta \mathrm{Ct}$ values were then calculated based on the formula $\Delta \Delta \mathrm{Ct}=\Delta \mathrm{Ct}$ treated - $\Delta \mathrm{Ct}$ untreated. The expression level of the target gene in the treated cells was measured relative to the level observed in the untreated cells and was quantified using the formula $2^{-\Delta \Delta \mathrm{CT}}$ (22). The PCR products were electrophoresed on a $2 \%$ agarose gel and stained by ethidium bromide under UV light.

Statistical analysis. The results of each experiment were expressed as the means \pm standard deviation (SD, for each group $n=3$ ). The data were processed with the GraphPad Prism 


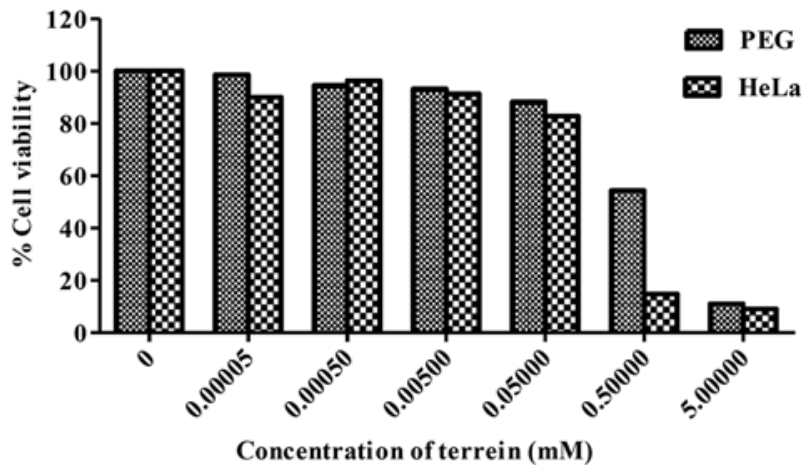

Figure 2. The effect of terrein on cell viability as determined by the MTT assay. HeLa and PEG cells were treated with various concentrations of terrein $(\mathrm{mM})$ for $24 \mathrm{~h}$. Control cell cultures were exposed to the vehicle, $1 \%$ DMSO. Data are expressed as the means $\pm \mathrm{SD}, \mathrm{n}=3$.

5 software. Statistical significance was assessed by one-way ANOVA analysis of variance to evaluate the significance of differences between the groups.

\section{Results}

Effect of terrein on cell viability. Terrein was tested for its cytotoxicity against human cervical cancer cells (HeLa) and normal cells (PEG) by the MTT assay. As shown in Fig. 2, terrein significantly inhibited the growth of PEG and HeLa cells in relation to the concentration used. The $\mathrm{IC}_{50}$ values were at $0.53 \mathrm{mM}$ for PEG and $0.29 \mathrm{mM}$ for HeLa. It is noteworthy that the percentage of cell viability comparing the cancer and the normal cells differed significantly when using terrein at a concentration of $0.5 \mathrm{mM}$ which was approximately 18 and $60 \%$, respectively. The results indicate a considerable potential of the cytotoxicity effect on human cervical cancer HeLa cells with lower toxicity on normal PEG cells.
Terrein induces apoptosis in HeLa cells. To evaluate the mode of cell death induced by terrein in HeLa cells, the experiment was carried out by staining cells with the DNA specific dye, Hoechst 33342. The cell samples were compared between the terrein-treated cells and the untreated control HeLa cells. The concentrations of terrein were $0,0.3,0.6$ and $1.5 \mathrm{mM}$ and were treated for $24 \mathrm{~h}$. As depicted in Fig. 3, the untreated control cells displayed normal, round nuclei (Fig. 3a), while the cells treated with terrein exhibited characteristics of apoptosis, such as cell shrinkage, nuclear condensation and fragmentation in a dose-dependent manner (Fig. 3b-d).

As the apoptotic cells with fragmented nuclei appear as cells with hypodiploid DNA content and could be detected at sub-G0 peak with flow cytometry, the numbers of the apoptotic sub-G0 population were quantified. The result demonstrated that the terrein-treated HeLa samples had significantly increased in the sub-G0 phase as compared to the untreated sample (Fig. 4Aa-d). The statistics of each phase of the cell cycle showed that the sub-G0 populations increased as the doses of terrein increased from 11.90 to 26.37 and $84.93 \%$. (Fig. 4B). These results suggest that apoptosis is the mode of cell death used by terrein against HeLa cells.

Induction of apoptotic signaling is triggered by the death receptor and the mitochondrial pathway. Apoptosis is triggered by sequential activation of caspases, a group of cysteine proteases, and proceeds primarily through two pathways. The extrinsic or death receptor pathway involves activation of caspase- 8 and is initiated by ligand interaction with death receptors. Second, the intrinsic or mitochondrial pathway is activated by an imbalance between pro-apoptotic and antiapoptotic proteins from the $\mathrm{Bcl}-2$ family at the mitochondria and cytosol, resulting in the release of cytochrome $c$ from the mitochondria, which in turn activates caspase-9. Both caspase- 8 and caspase- 9 activate caspase- 3 which acts as a common downstream part of the two major apoptosis path-
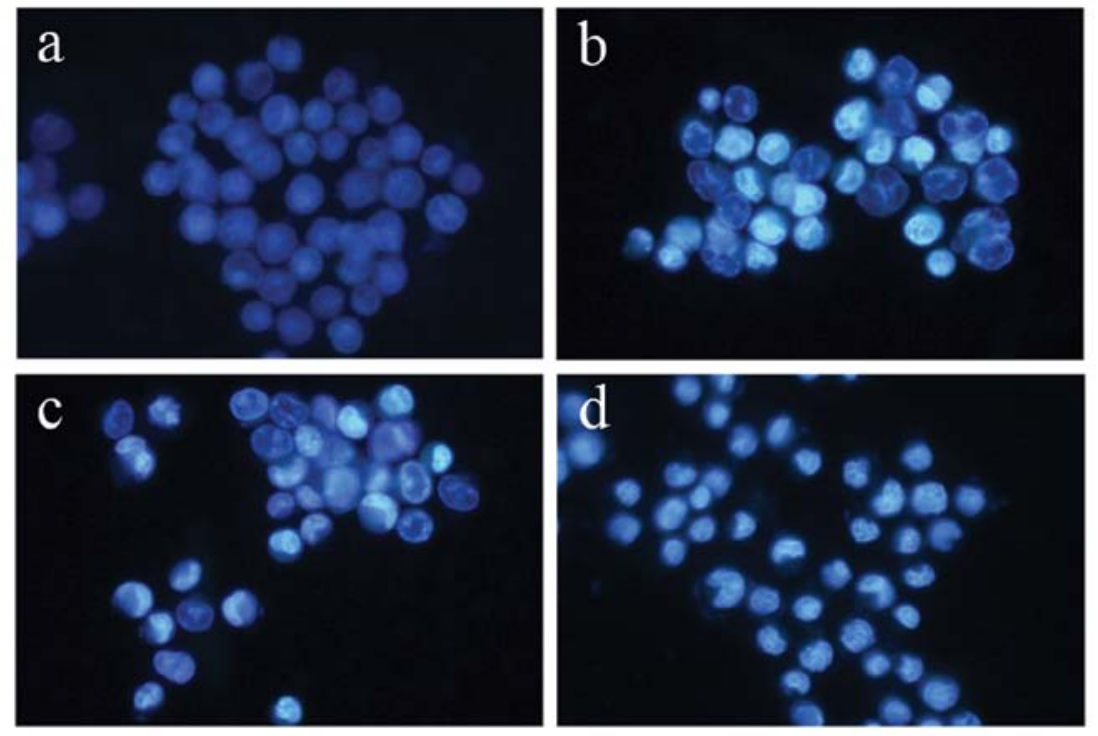

Figure 3. The changes of the nuclear morphology of cervical cancer cells upon treatment with terrein. HeLa cells treated with terrein at (a) 0 , (b) 0.3 , (c) 0.6 and (d) $1.5 \mathrm{mM}$ for $24 \mathrm{~h}$ were fixed and stained with the DNA binding dye Hoechst 33342. Condensed and fragmented nuclei were observed under a fluorescent microscope. Condensed and fragmented nuclei were observed under a fluorescent microscope $(\mathrm{x} 400)$. 

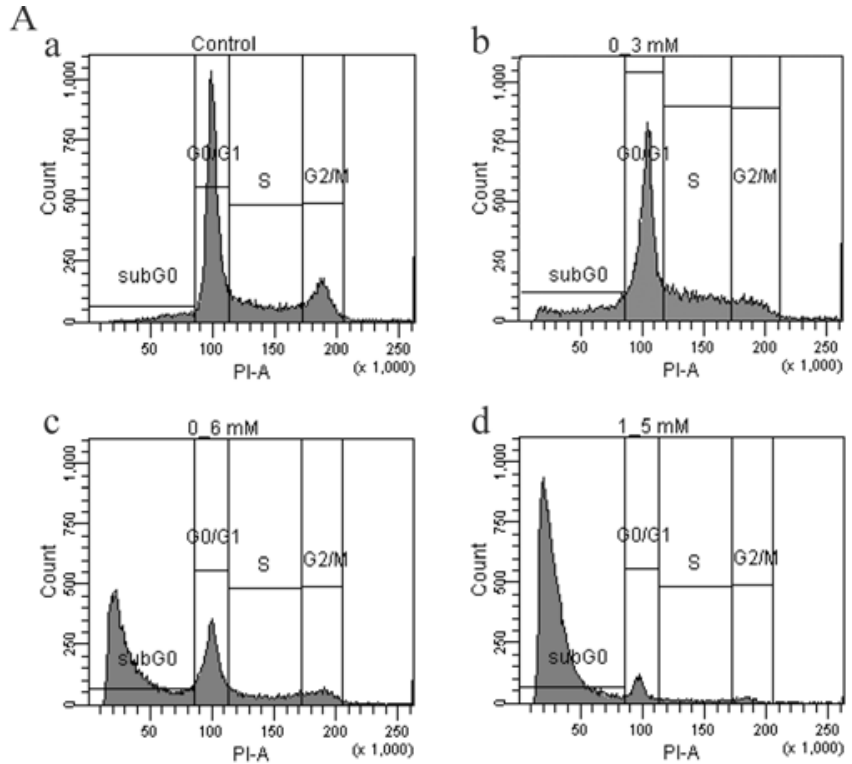

B

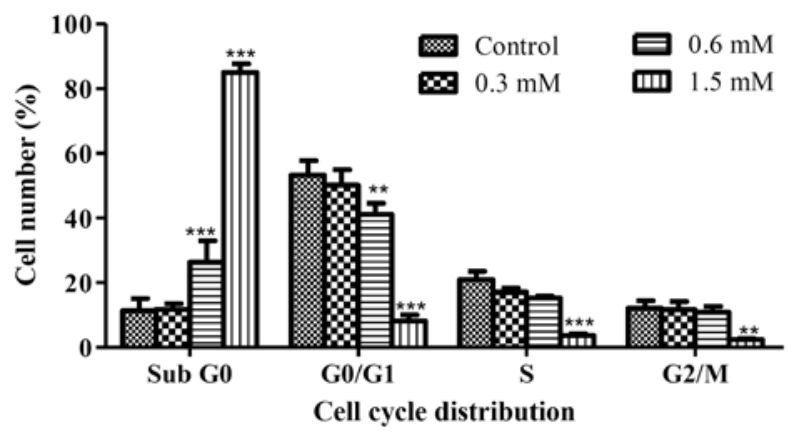

Figure 4. The effect of terrein on the cell cycle distribution of cervical cancer cells upon terrein treatment. (A) HeLa cells were treated with terrein at (a) 0 , (b) 0.3 , (c) 0.6 and (d) $1.5 \mathrm{mM}$ for $24 \mathrm{~h}$ and analyzed by flow cytometry. Histograms show the number of cells per channel (vertical axis) vs. the DNA content (horizontal axis). The data shown are representative of three independent experiments with similar findings. (B) The values indicate the percentage of cells at the indicated phases of the cell cycle. The significant differences of the treated cells from the untreated control group are indicated by ${ }^{* *} \mathrm{P}<0.01,{ }^{* * *} \mathrm{P}<0.001$.

ways resulting in apoptosis (23). To address the apoptotic pathway in the terrein-treated HeLa cells, measuring of the fluorogenic substrate cleavage was performed. The result of the fluorescence intensity showed that terrein significantly activated caspase-8, caspase- 9 and caspase- 3 function after $12 \mathrm{~h}$ of treatment. Caspase activity increased significantly when compared to the control group of untreated cells in a concentration-dependent manner (Fig. 5). In addition, the activity of each caspase was inhibited by their specific inhibitor provided by the kit (data not shown). These results suggest that terrein activates the signaling of both the death receptor and mitochondrial pathways.

To confirm the cascade, the damage to the mitochondria was analyzed using a specific dye for mitochondrial, JC-1, staining. Upon quantification by flow cytometry, the HeLa cells treated with terrein at $6 \mathrm{~h}$ presented with decreasing $\Delta \Psi \mathrm{m}$ as compared to the control group of untreated cells in a dose-dependent manner (Fig. 6). Then, we investigated the expression of Bcl-2 family proteins and whether they were involved with the damage to the mitochondria. The expression

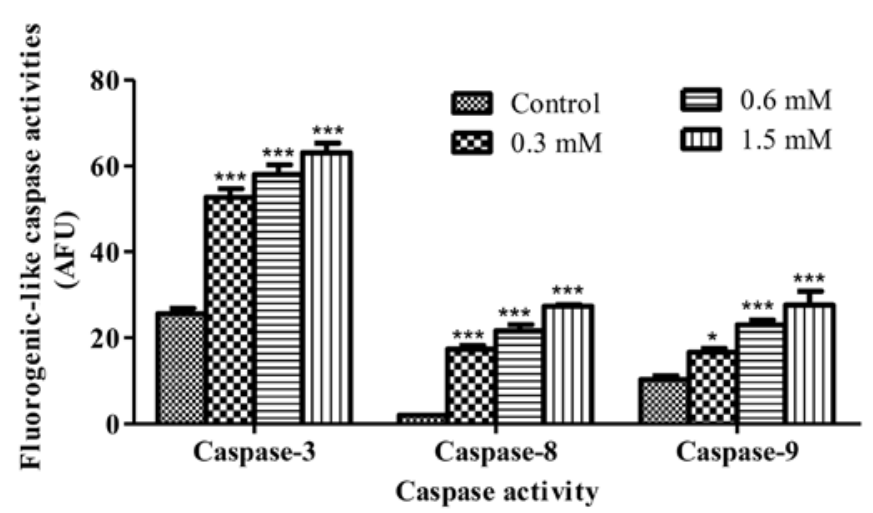

Figure 5. The activation of cellular caspase-3, -8 and -9 in cervical cancer cells after terrein treatment. Lysate from HeLa cells treated with terrein $(0$, $0.3,0.6$ and $1.5 \mathrm{mM}$ ) for $12 \mathrm{~h}$ were used to measure the catalytic activity of caspase by using fluorogenic substrates. The data shown are representative of three independent experiments. The significant differences from control are indicated by ${ }^{*} \mathrm{P}<0.05,{ }^{* * *} \mathrm{P}<0.001$.

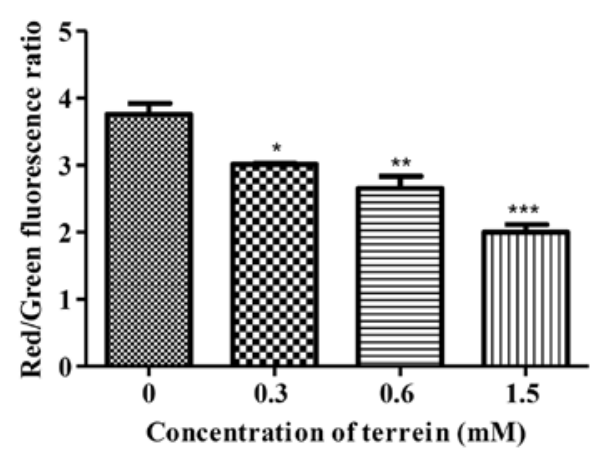

Figure 6. The dissipation of mitochondrial membrane potential of cervical cancer cells upon treatment with terrein. HeLa cells treated with different concentrations of terrein $(0,0.3,0.6$ and $1.5 \mathrm{mM})$ for $6 \mathrm{~h}$ were stained with JC-1 and the average ratio of red/green fluorescence intensity was analyzed by flow cytometry. The data shown are representative of three independent experiments. The significant differences from control are indicated by ${ }^{*} \mathrm{P}<0.05,{ }^{* *} \mathrm{P}<0.01,{ }^{* * *} \mathrm{P}<0.001$.

of Bax (pro-apoptotic) and $B c l-2$ (anti-apoptotic) was selected for investigation. As a result, terrein increased the expression of Bax (Fig. 7a) and decreased the expression of Bcl-2 (Fig. 7b) in a dose-dependent manner by real-time PCR. An increase in the $\mathrm{Bax} / \mathrm{Bcl}-2$ ratio (Fig. $7 \mathrm{c}$ ) indicates that upregulation of these Bcl-2 family proteins are upstream events causing damage to the mitochondria.

Apoptotic signaling is mediated by $p 53$ and ERK activation. The tumor suppressor gene, $p 53$, is known to be responsible for the inhibition of cell growth and/or the commitment to apoptosis. Meanwhile, p53 protein regulates the expression of the downstream effector $\mathrm{p} 21$, a potent inhibitor of cell cycle kinases, in which both are in response for DNA damage. In addition, p53 regulates apoptosis via upregulation of the expression of Bax and blocks the function of Bcl-2. Thus, it is possible that a substantial increase in the $\mathrm{Bax} / \mathrm{Bcl}-2$ ratio may have resulted from p53 function. The level of the expression of p53 and $p 21$ were then examined. As shown in Fig. $8 \mathrm{a}$ and b, the expression of mRNA from both $p 53$ and $p 21$ was upregulated suggesting 
$\mathrm{a}$

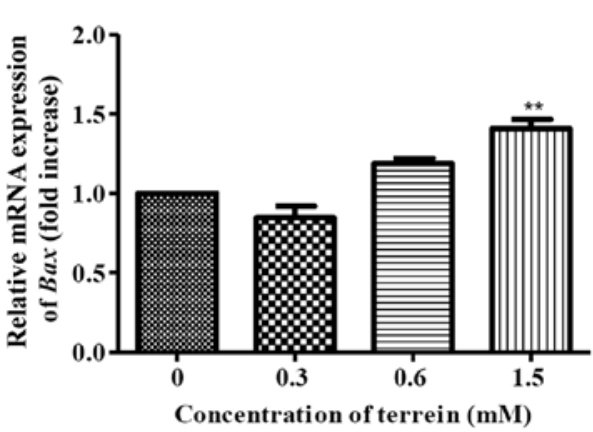

$\mathrm{c}$

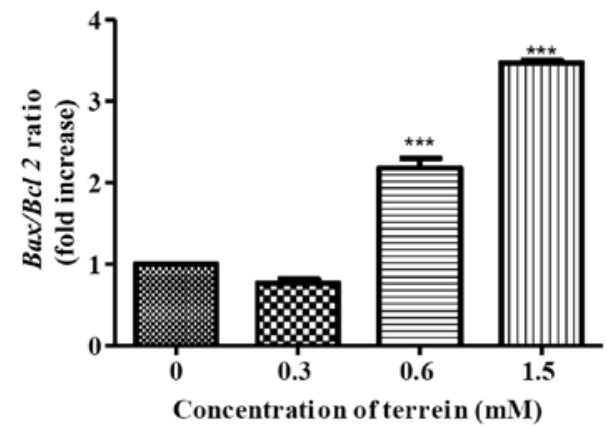

b

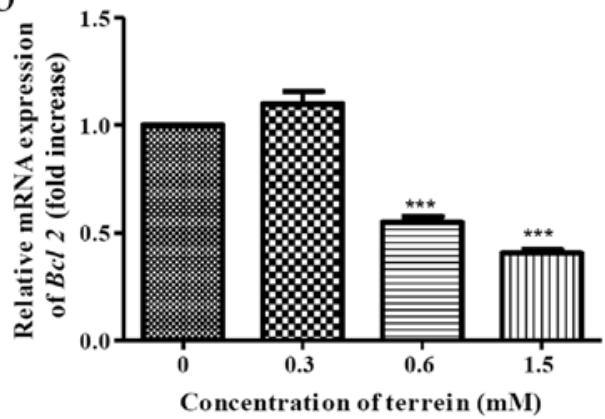

d

$0 \mathrm{mM} \quad 0.3 \mathrm{mM} \quad 0.6 \mathrm{mM} \quad 1.5 \mathrm{mM}$

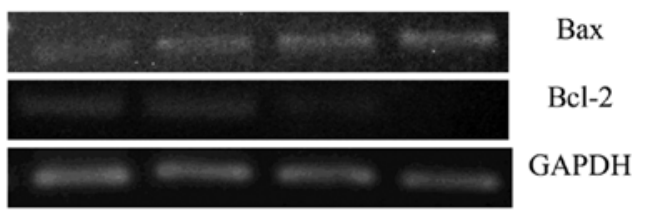

Figure 7. Dose-dependent effects of terrein on $B c l 2$ and Bax mRNA expression levels in HeLa cells, treated with different concentrations of terrein ( $0,0.3$, 0.6 and $1.5 \mathrm{mM}$ ) for $24 \mathrm{~h}$. mRNA expression levels were determined by quantitative real-time PCR. GAPDH mRNA was used as an internal control. (a) The relative gene expression level of Bax. (b) The relative gene expression level of $B c l-2$. (c) Bar charts show the ratio of $B a x / B c l-2$, analyzed from the quantitative real time-PCR results. (d) PCR products were analyzed by agarose gel electrophoresis and stained with ethidium bromide. The data shown are representative of three independent experiments. The significant differences from control are indicated by ${ }^{* *} \mathrm{P}<0.01,{ }^{* * *} \mathrm{P}<0.001$.

a

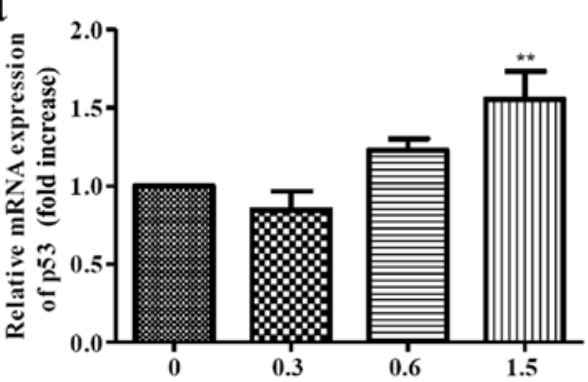

c

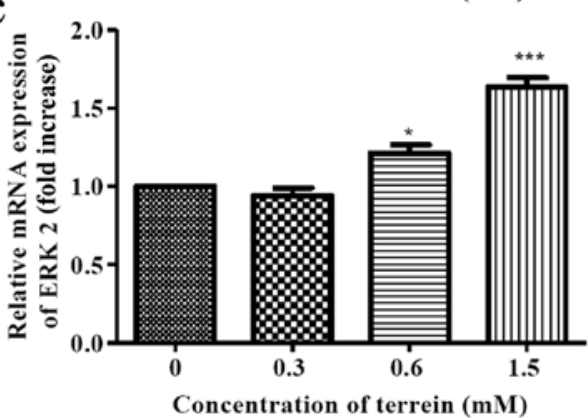

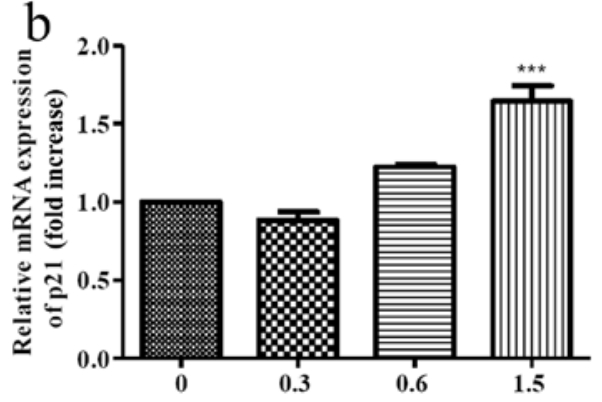

d

Concentration of terrein $(\mathrm{mM})$

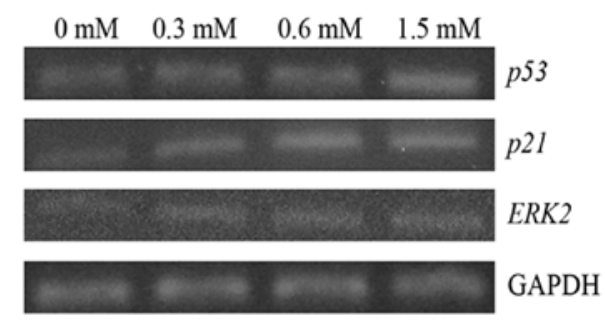

Figure 8. Dose-dependent effects of terrein on $p 53, p 21$ and $E R K 2$ mRNA expression levels in HeLa cells, treated with different concentrations of terrein $(0,0.3$, 0.6 and $1.5 \mathrm{mM}$ ) for $24 \mathrm{~h}$. mRNA expression levels were determined by quantitative real-time PCR. GAPDH mRNA was used as an internal control. (a) The relative gene expression level of $p 53$. (b) The relative gene expression level of $p 21$. (c) The relative gene expression level of $E R K 2$. (d) PCR products were analyzed by agarose gel electrophoresis and stained with ethidium bromide. The significant differences from control are indicated by ${ }^{*} \mathrm{P}<0.05,{ }^{* * *} \mathrm{P}<0.01,{ }^{* * *} \mathrm{P}<0.001$.

that the upstream signaling of the mitochondrial pathway was induced by terrein. To investigate this signaling triggered by terrein, further upstream mediators of p53 were evaluated. As is well known, several protein kinases may function to activate p53 and ERK2 may be the kinase that is responsible for the
DNA damage. Therefore, we selected ERK2 to study the level of expression in response to the terrein treatment. As depicted in Fig. 8c, the mRNA expression of ERK2 increased following terrein treatment in a dose-dependent manner indicating the involvement of ERK signaling. 


\section{Discussion}

The present study is the first to demonstrate that terrein, a fungal metabolite, induces apoptosis in cervical cancer cells via p53 and ERK signaling. As previously shown, terrein has a variety of effects including anti-inflammatory (13), anti-oxidant (14), anti-proliferative (15) and skin-whitening properties (11-12). The effects of terrein on cancer cells have also been reported. In androgen-dependent prostate cancer cells (LNCaP-CR), terrein demonstrates angiogenesis inhibition by blocking the secretion of angiogenin with an $\mathrm{IC}_{50}$ of $13 \mu \mathrm{M}$ (16). In human lung tumoral cell lines (NCI-H292), terrein acts as proteasome inhibitor by suppressing the chymotrypsin- and trypsin-like activities with the $\mathrm{IC}_{50}$ of $0.3 \mathrm{mM}$. Also, in these lung tumor cells, terrein was able to induce apoptotic cell death at concentrations of $0.15 \mathrm{mM}$ and $0.3 \mathrm{mM}(10)$. In breast cancer cells (MCF-7), terrein markedly inhibited cell proliferation in $\mathrm{IC}_{50}$ of $1.1 \mathrm{nM}$ (17). Meanwhile, for normal cells, it has been shown that terrein has of non-cytotoxic effects in human keratinocyte at the concentration of 1-50 $\mu \mathrm{M}$ (15). Comparing these data, our study found that the $\mathrm{IC}_{50}$ for cervical cancer cells was at $0.29 \mathrm{mM}$, while in normal porcine epithelial glandular (PEG) cells it was at $0.53 \mathrm{mM}$ (Fig. 2). These data suggest that the dose of terrein to induce cancer cell death is cell typedependent. The concentration appears to be high ( $\mathrm{mM}$ range) but this effective dose has almost the same value exhibited in lung tumor cells. The inhibition concentration at $50 \%$ of terrein treatment in HeLa cells did not differ significantly from normal PEG cells. This indicates that terrein also exhibits cytotoxic action on normal cells. However, at approximately $0.5 \mathrm{mM}$ of terrein, the percentage of cell viability of HeLa cells was approximately $18 \%$, while in the normal PEG cells it was approximately $60 \%$ which was represented by the difference in the sensitivity.

The evaluation of the mechanism used by terrein to trigger cervical cancer cell death is implicated via apoptosis. As shown in Figs. 2-5, chromatin condensation, DNA fragmentation and caspase activation were clearly demonstrated. These are distinct characteristics of the apoptosis mechanism (24). To develop an anticancer agent, apoptosis is the preferable mechanism as it does not trigger the inflammation process observed in necrosis, another form of cell death. As previously shown, several anticancer drugs use apoptosis as their target mechanism, therefore, terrein is another promising compound for development as an anticancer agent (4-7).

The pathway to induce apoptosis is initiated by two major pathways, the extrinsic or death receptor pathway and the intrinsic or mitochondrial pathway. The extrinsic pathway integrates extracellular signals through the binding of external ligands to death receptors located at the plasma membrane such as the Fas/FasL interaction. Engagement of these receptors by their specific ligand induces their trimerization and leads to the assemblage of the death-inducing signaling complex (DISC). In this complex, procaspase- 8 is activated and in turn cleaves and activates executioner caspases including caspase- 3 , caspase- 6 or caspase- $7(25,26)$. The intrinsic pathway is triggered by the activation of the pro-apoptotic Bcl-2 family proteins known as Bax or Bak. These proteins have shown the ability to form pores in the mitochondrial outer membranes, thereby allowing permea- bilization of cytochrome $c$ release to cytosol. Cytochrome $c$ binds to the adaptor apoptotic protease activating factor-1 (Apaf-1) forming a large multi-protein structure known as the apoptosome. The apoptosome then recruits and activates procaspase-9 into the active form which further activates the downstream effector caspases for the death receptor pathway, finally resulting in cell death $(27,28)$.

However, several reports have shown that the cascade of the extrinsic and intrinsic pathway is not fully separated in some cases. Caspase- 8 can initiate death via caspase- 3 directly or it can trigger the mitochondrial pathway via Bid cleavage (25). Cells that perform directly to the cascade from caspase- 8 to caspase-3 are called type I cells, while the cells relative to the cascade initiated from caspase- 8 and that have death enhancement via the mitochondrial pathway are called type II cells (29). As shown in this study, terrein activates both caspase-8 and caspase-9 (Fig. 5). Also, the changes in the ratio of $B a x / B c l-2$ expression and the dissipation of the $\Delta \Psi \mathrm{m}$ were detected (Figs. 6 and 7). These data suggested that terreininduced apoptosis in cervical cancer cells may display as type II signaling, which is consistent with the reports that HeLa cells triggered by apoptosis-inducing agents usually perform as type II cells $(30,31)$.

p53 plays an important role in several cellular processes. It controls the cell cycle, cell senescence and cell apoptosis. To regulate the apoptosis mechanism, p53 mediates the expression of several proteins that are involved in the release of cytochrome $c$ from the mitochondria, and Bax, Noxa, Puma, AIP1 and APAF1 are also included (32). We also demonstrated that Bax is upregulated upon treatment with terrein, and this may be due to the function of the transcriptional activation by $\mathrm{p} 53$. As shown by our results, the level of $p 53$ expression increased upon treatment with terrein (Fig. 8a). In addition, the level of $p 21$, the cyclin-dependent kinase 2 inhibitor that is transcriptionally activated by $\mathrm{p} 53$, was also upregulated (Fig. 8b). These data support the critical role of p53 in terreinmediated cervical cancer cell death which correlates with previous studies of bioactive agents, such as capsaicin (33), eurycomanone (34), flavonoid quercetin (35), kaempferol-7-O$\beta$-D-glucoside (36) and cisplatin (37).

Our study also analyzed the role of extracellular signalregulated kinase (ERK) signaling and whether or not it is involved in terrein-induced apoptotic cell death. As previously described, ERK2 is involved in cell death by interaction with phosphorylated p53 (38). Thus, we determined the level of ERK2 expression in response to terrein treatment. As depicted in Fig. 8c, the level of the expression of $E R K 2$ increased in a dose-dependent manner. These data suggest that ERK may act upstream of p53 and that consequently leads to cell death by apoptosis. In addition, it has been reported in HeLa cells that ERK activation is associated with the upregulation of p53 expression upon treatment with shikonin (39) and $\mathrm{H}_{2} \mathrm{O}_{2}$ (40). Otherwise, it is assumed that ERK may act upon the activation of caspase-8. As it has been shown, the prolonged activation of ERK1/2 induces FADDindependent caspase- 8 activation and cell death $(41,42)$. As is demonstrated by our study, the upregulation of $E R K 2$ is possibly an important mediator that activates $\mathrm{p} 53$, caspase- 8 and caspase-9, leading to the destruction of the cancer cells. 
In conclusion, our study demonstrated that terrein is a potential candidate as an anticancer agent as it was shown to induce cytotoxicity and apoptosis in cervical cancer cells. The apoptosis pathway may be type II signaling which mediates through ERK signaling. ERK acts as a mediator to regulate the activation of both caspase- 8 and p53. The downstream effect of the p53, particularly Bax, was upregulated and significantly leads to the dissipation of the $\Delta \Psi \mathrm{m}$. Consequently, caspase-9 and caspase- 3 are activated finally initiating the cleavage of all cellular substrates and genetic materials.

\section{Acknowledgements}

This study was supported by the Commission on Higher Education, Ministry of Education and Faculty of Medicine, Srinakharinwirot University, Thailand.

\section{References}

1. Jit M, Demarteau N, Elbasha E, Ginsberg G, Kim J, Praditsitthikorn N, Sinanovic E and Hutubessy R: Human papillomavirus vaccine introduction in low-income and middleincome countries: guidance on the use of cost-effectiveness models. BMC Med 54: 2-9, 2011.

2. Thomas GM: Improved treatment for cervical cancer-concurrent chemotherapy and radiotherapy. N Engl J Med 340: 1198-1200, 1999.

3. Ren G, Zhao YP, Yang L and Fu CX: Anti-proliferative effect of clitocine from the mushroom Leucopaxillus giganteus on human cervical cancer HeLa cells by inducing apoptosis. Cancer Lett 262: 190-200, 2008

4. Park SJ, Wu CH, Gordon JD, Zhong X, Emami A and Safa AR: Taxol induces caspase-10-dependent apoptosis. J Biol Chem 279: 51057-51067, 2004.

5. Wang S, Konorev EA, Kotamraju S, Joseph J, Kalivendi S and Kalyanaraman B: Doxorubicin induces apoptosis in normal and tumor cells via distinctly different mechanisms. J Biol Chem 279: 25535-25543, 2004.

6. Day TW, Wu CH and Safa AR: Etoposide induces protein kinase $\mathrm{C} \delta$ - and caspase-3 dependent apoptosis in neuroblastoma cancer cells. Mol Pharmacol 76: 632-640, 2009.

7. Tanida S, Mizoshita T, Ozeki K, Tsukamoto H, Kamiya T, Kataoka H, Sakamuro D and Joh T: Mechanisms of cisplatininduced apoptosis and of cisplatin sensitivity: potential of BIN1 to act as a potent predictor of cisplatin sensitivity in gastric cancer treatment. Int J Surg Oncol 2012: 862879, 2012.

8. Newman DJ and Cragg GM: Microbial antitumor drugs: natural products of microbial origin as anticancer agents. Curr Opin Investig Drugs 10: 1280-1296, 2009.

9. Raistrick H and Smith G: Studies in the biochemistry of microorganisms: the metabolic products of Aspergillus terreus Thom A new mould metabolic product-terrein. Biochem J 29: 606-611, 1935.

10. Demasi M, Felicio AL, Pacheco AO, Leite HG, Lima C and Andrade LH: Studies on terrein as a new class of proteasome inhibitors. J Braz Chem Soc 21: 299-305, 2010.

11. Park SH, Kim DS, Kim WG, Ryoo IJ, Lee DH, Huh CH, Youn SW Yoo ID and Park KC: Terrein: a new melanogenesis inhibitor and its mechanism. Cell Mol Life Sci 61: 2878-2885, 2004.

12. Kim DS, Lee S, Lee HK, Park SH, Ryoo IJ, Yoo ID, Kwon SB, Baek KJ, Na JI and Park KC: The hypopigmentary action of KI-063 (a new tyrosinase inhibitor) combined with terrein. J Pharm Pharmacol 60: 343-348, 2008.

13. Lee JC, Yu MK, Lee R, Lee YH, Jeon JG, Lee MH, Jhee EC, Yoo ID and Yi HK: Terrein reduces pulpal inflammation in human dental pulp cells. J Endod 34: 433-437, 2008

14. Lee YH, Lee NH, Bhattarai G, Oh YT, Yu MK, Yoo ID, Jhee EC and Yi HK: Enhancement of osteoblast biocompatibility on titanium surface with Terrein treatment. Cell Biochem Funct 28 678-685, 2010

15. Kim DS, Lee HK, Park SH, Lee S, Ryoo IJ, Kim WG, Yoo ID, Na JI, Kwon SB and Park KC: Terrein inhibits keratinocyte proliferation via ERK inactivation and G2/M cell cycle arrest. Exp Dermatol 17: 312-317, 2007.
16. Arakawa M, Someno T, Kawada M and Ikeda D: A new terrein glucoside, a novel inhibitor of angiogenin secretion in tumor angiogenesis. J Antibiot 61: 442-448, 2008.

17. Liao WY, Shen CN, Lin LH, Yang YL, Han HY, Chen JW, Kuo SC, Wu SH and Liaw CC: Asperjinone, a nor-neolignan, and terrein, a suppressor of ABCG2-expressing breast cancer cells, from thermophilic Aspergillus terreus. J Nat Prod 75: 630-635, 2012.

18. Uthaisang W, Reutrakul V, Krachangchaeng C, Wilairat P and Fadeel B: VR-3848, a novel peptide derived from Euphobiaceae, induces mitochondria-dependent apoptosis in human leukemia cells. Cancer Lett 208: 171-178, 2004.

19. Oubrahim H, Stadtman ER and Chock PB: Mitochondria play no roles in $\mathrm{Mn}$ (II)-induced apoptosis in HeLa cells. Proc Natl Acad Sci USA 98: 9505-9510, 2001.

20. Feng Q, Cao HL, Xu W, Li XR, Ren YQ and Du LF: Apoptosis induced by genipin in human leukemia K562 cells: involvement of c-Jun N-terminal kinase in G2/M arrest. Acta Pharmacol Sin 31: 519-527, 2011.

21. Cossarizza A, Baccarani CM, Kalashnikova $G$ and Franceschi C: A new method for the cytofluorimetric analysis of mitochondrial membrane potential using the J-aggregate forming lipophilic cation 5,5',6,6'-tetrachloro-1,1',3,3'-tetraethylbenzimidazolcarbocyanine iodide (JC-1). Biochem Biophys Res Commun 197: 40-45, 1993.

22. Gomez-Lazaro M, Galindo MF, Concannon CG, Segura MF, Fernandez-Gomez FJ, Llecha N, Comella JX, Prehn JH and Jordan J: 6-Hydroxydopamine activates the mitochondrial apoptosis pathway through p38 MAPK-mediated, p53-independent activation of Bax and PUMA. J Neurochem 104: 1599-1612, 2008.

23. Puerto HLD, Martins AS, Milsted A, Souza-Fagundes EM, Braz GF, Hissa B, Andrade LO, Alves F, Rajão DS, Leite RC and Vasconcelos AC: Canine distemper virus induces apoptosis in cervical tumor derived cell lines. Virol J 334: 2-7, 2011.

24. Elmore S: Apoptosis: a review of programmed cell death. Toxicol Pathol 35: 495-516, 2007.

25. Ashkenazi A: Targeting the extrinsic apoptosis pathway in cancer. Cytokine Growth Factor Rev 19: 325-331, 2008.

26. Gu Q, Wang JD, Xia HHX, Lin MC, He H, Zou B, Tu SP, Yang Y, Liu XG, Lam SK, Wong WM, Chan AO, Yuen MF, Kung HF and Wong BC: Activation of the caspase-8/Bid and Bax pathways in aspirin-induced apoptosis in gastric cancer. Carcinogenesis 26: 541-546, 2005.

27. Budihardjo I, Oliver H,Lutter M, Luo X and Wang X: Biochemical pathways of caspase activation during apoptosis. Annu Rev Cell Dev Biol 15: 269-290, 1999.

28. Ghobrial IM, Witzig TE and Adjei AA: Targeting apoptosis pathways in cancer therapy. CA Cancer J Clin 55: 178-194, 2005.

29. Jin Z, Li Y, Pitti R, Lawrence D, Pham VC, Lill JR and Ashkenazi A: Cullin3-based polyubiquitination and p62-dependent aggregation of caspase- 8 mediate extrinsic apoptosis signaling. Cell 137: 721-735, 2009.

30. Kim SH, Kim SH, Lee SC and Song YS: Involvement of both extrinsic and intrinsic apoptotic pathways in apoptosis induced by genistein in human cervical cancer cells. Ann NY Acad Sci 1171: 196-201, 2009.

31. Hougardy BM, van der Zee AG, van den Heuvel FA, Timmer T, de Vries EG and de Jong S: Sensitivity to Fas-mediated apoptosis in high-risk HPV-positive human cervical cancer cells: relationship with Fas, caspase-8, and Bid. Gynecol Oncol 97: 353-364, 2005.

32. Gross A, Jockel J, Wei MC and Korsmeyer SJ: Enforced dimerization of $\mathrm{BAX}$ results in its translocation, mitochondrial dysfunction and apoptosis. EMBO J 17: 3878-3885, 1998.

33. Yang W, Gong X, Zhao X, An W, Wang X and Wang M: Capsaicin induces apoptosis in HeLa cells via Bax/Bcl-2 and caspase-3 pathways. Asian J Traditional Med 1: 3-4, 2006.

34. Mahfudh N and Pihie AHL: Eurycomanone induces apoptosis through the up-regulation of p53 in human cervical carcinoma cells. J Cancer Mol 4: 109-115, 2008.

35. Priyadarsini RV, Murugan RS, Maitreyi S, Ramalingam K, Karunagaran D and Nagini S: The flavonoid quercetin induces cell cycle arrest and mitochondria-mediated apoptosis in human cervical cancer $(\mathrm{HeLa})$ cells through p53 induction and $\mathrm{NF}-\kappa \mathrm{B}$ inhibition. Eur J Pharmacol 649: 84-91, 2010.

36. Xu W, Liu J, Li C, Wu HZ and Liu YW: Kaempferol-7- $O-\beta-\mathrm{D}-$ glucoside (KG) isolated from Smilax china L. rhizome induces $\mathrm{G}_{2} / \mathrm{M}$ phase arrest and apoptosis on HeLa cells in a p53-independent manner. Cancer Lett 264: 229-240, 2008. 
37. Wang X, Martindale JL and Holbrook NJ: Requirement for ERK activation in cisplatin-induced apoptosis. J Biol Chem 275: 39435-39443, 2000

38. Yeh PY, Chuang SE, Yeh KH, Song YC, Chang LLY and Cheng AL: Phosphorylation of p53 on Thr55 by ERK2 is necessary for doxorubicin-induced p53 activation and cell death. Oncogene 23: 3580-3588, 2004.

39. Wu Z, Wu LJ, Tashiro S, Onodera S and Ikejima T: Phosphorylated extracellular signal-regulated kinase up-regulated p53 expression in shikonin-induced HeLa cell apoptosis. Chin Med J 118 671-677, 2005
40. Singh M, Sharma H and Singh N: Hydrogen peroxide induces apoptosis in HeLa cells through mitochondrial pathway. Mitochondrion 7: 367-373, 2007.

41. Zhuang S and Schnellmann RG: A death-promoting role for extracellular signal-regulated kinase. J Pharmacol Exp Ther 319: 991-997, 2006

42. Cagnol S and Chambard JC: ERK and cell death: mechanisms of ERK-induced cell death-apoptosis, autophagy and senescence. FEBS J 277: 2-21, 2010. 